\title{
EMISSIONS FROM INDIRECT LAND USE CHANGE: DO THEY MATTER WITH FUEL MARKET LEAKAGES?
}

\author{
Dušan Drabik* ${ }^{1,2}$, Harry de Gorter ${ }^{1}$
}

\author{
Address: Dušan Drabik, \\ ${ }^{1}$ Cornell University, Charles H. Dyson School of Applied Economics and Management, B32 Warren Hall, Ithaca, NY 14853-7801 phone: +1 607- \\ $255-8076$ \\ ${ }^{2}$ LICOS - Centre for Institutions and Economic Performance, Waaistraat 6 - bus 3511, B-3000 Leuven - Belgium \\ *Corresponding author: dd387@cornell.edu
}

\begin{abstract}
Indirect land use change, an agricultural market leakage, has been a major controversy over the Environmental Protection Agency's (EPA) requirement for corn-ethanol to reduce greenhouse gas (GHG) emissions by 20 percent relative to gasoline it is assumed to replace. This paper shows that corn-ethanol policies generate far greater carbon leakage in the fuel market itself. Hence, corn-ethanol does not meet EPA's threshold, regardless of ethanol policy and whether one includes emissions from land use change.
\end{abstract}

Keywords: biofuels, ethanol, carbon leakage, emissions savings, tax credit, mandate JEL: Q27, Q41, Q42, Q54

\section{INTRODUCTION}

The issue of carbon leakage - where greenhouse gas (GHG) emissions reductions by an environmental policy are partially or more than offset because of market effects - is often raised as an issue that will undermine environmental policies. Leakage has been extensively studied in the cases of cap and trade policies (see Wooders and Cosbey 2009 for a survey), reduced deforestation and land degradation - REDD (e.g., Murray 2008) and indirect land use change generated from biofuels policies (e.g., Searchinger et al. 2008; AlRiffai, et al. 2010 provide one of many surveys on indirect land use change).

While emissions from land use change due to biofuel policies has attracted a significant amount of research, the same is not true for leakage in the fuel market itself - the focus of this paper - where the addition of biofuels causes a reduction in world oil (gasoline) market prices (Drabik 2011; Hochman et al. 2011). ${ }^{1,2}$ To our knowledge, de Gorter and Just (2009a) were the first to point to this effect (calling it the "indirect output use effect"), but they only discuss the intuition and do not provide an analysis for individual biofuel policies. Chen et al. (2011) use a dynamic, spatial, multi-market equilibrium model to examine the

\footnotetext{
${ }^{1}$ In other words, we seek to quantify the market changes in the fuel market resulting from the introduction of biofuels via various biofuel policies. This means, production of biofuels is the only shock to the fuel market we analyze; therefore, we do not investigate how much would world oil consumption change, for example, due to a shock in the oil price.

${ }^{2}$ Assuming the crude oil price is endogenous.
}

extensive and intensive margin changes in land use in the United States induced by biofuel policies and the implications of these policies for GHG emissions. Although they also provide estimates of leakage in the fuel market, they model the biofuel mandate differently. Namely, they assume consumers enjoy a choice between ethanol and gasoline even when the use of the former is mandated; hence, in their model the ethanol price (in energy equivalent) is equal to the price of gasoline. In our model, the price of fuel (i.e., blend of ethanol and gasoline) is a weighted average of the ethanol and gasoline price (in energy equivalents), where the weights are represented by the share of ethanol and gasoline.

Rajagopal et al. (2011) empirically estimate fuel market leakage related to the U.S. ethanol blend mandate and find that the mandate combined with a blender's tax credit result in a reduction in global carbon emissions. ${ }^{3}$ More recently, however, Rajagopal and Plevin (2013) showed that Rajagopal et al. (2011)'s results are likely to occur with a low probability (five percent or less). This is consistent with our results as we find that the cornethanol is associated with an increase in carbon emissions. ${ }^{4,5}$ Rajagopal (2013) provides a survey of

\footnotetext{
3 For ease of reference, under the term "carbon emissions" in the paper we mean carbon-equivalent greenhouse gas emissions at combustion. ${ }^{4} \mathrm{Du}$ and Hayes (2009) find that U.S. ethanol production pushes the wholesale gasoline prices down, but this is not leakage as it is defined in the literature. It is because they assume the oil price is fixed and look only at the oil crack ratio and spread. They also do not take into consideration the market effects outside the United States. We endogenize the world oil price, which gives rise to the indirect output use change effect in the fuel market.
} 
recent studies analyzing the fuel market leakage due to biofuel policies.

In 2007, legislation was introduced in the United States that requires one gasoline energy-equivalent gallon of ethanol to reduce GHG emissions by at least 20 percent relative to a gallon of gasoline that ethanol is assumed to replace. The 20 percent figure is the estimate based on "life-cycle accounting" (LCA), a "well to wheel" measure of GHGs emissions in the production of gasoline, and a "field to fuel tank" measure for ethanol production (Farrell et al. 2006). ${ }^{6}$ If this requirement is not met, corn ethanol cannot be counted towards the mandate.

With the recent concern over global climate change in the United States, the corn-ethanol lobby quickly seized upon the benefits of ethanol in reducing GHG emissions. But this strategy back-fired because LCA is inherently flawed, as highlighted by Searchinger et al. (2008) who showed U.S. corn-ethanol emits more GHGs relative to gasoline if changes in the use of land (e.g., converting forest into crop land) are taken into consideration. This sparked a controversy that reached a fever pitch and both the Environmental Protection Agency (EPA) and the California Air Resources Board (CARB) were then authorized to revise their estimate of ethanol's GHG savings to include emissions from indirect land use changes. ${ }^{7}$

This paper addresses the issue of whether cornethanol still meets the 20 percent threshold if fuel market leakage is taken into account. We define market leakage as a market effect of biofuels in not replacing gasoline and petroleum by-products consumption globally ${ }^{8}$. More specifically, the estimated LCA savings in emissions from a gasoline energy-equivalent gallon (GEEG) of ethanol assume ethanol replaces gasoline one to one, that is, it is assumed that there is no market leakage in the fuel market. But there inevitably is leakage in fuel markets, as there are in land and other markets related to biofuels production and consumption.

Our sensitivity analysis results show that one GEEG of ethanol replaces only 0.19 to 0.37 gallons of gasoline. The significant fuel market leakage combined with the land use effect makes one GEEG of ethanol emit as much as 16 percent more carbon than one gallon of gasoline. Thus, our key finding is that the U.S. corn ethanol does not meet the EPA's 20 percent sustainability standard.

\footnotetext{
${ }^{5}$ Earlier works by Drabik and de Gorter (2010) and Drabik et al. (2010) also predicted that U.S. corn ethanol increases global GHG emissions.

${ }^{6}$ The carbon savings of ethanol relative to gasoline in the LCA analysis occur because ethanol comes from feedstocks (e.g., corn) that are able to sequester carbon; there are also carbon savings in the process of producing ethanol.

${ }^{7}$ CARB made their ruling on land use change in April of 2009, while the EPA made their ruling in February 2010. The revised EPA ruling included not only an estimate of indirect land use change, but also a revised and substantially lower LCA estimate. As a result, even with indirect land use change, corn-ethanol still meets the threshold, provided relatively more ‘clean' inputs like natural gas are used instead in the production of ethanol.

${ }^{8}$ Life-cycle accounting that underpins the 0,1 sustainability thresholds, like the U.S. requirement that corn-ethanol reduce GHG emissions by 20 percent relative to gasoline, assumes one gasoline energy-equivalent gallon of ethanol replaces one gallon of gasoline.
}

Although we focus on the U.S. corn ethanol, the results of this study also apply to the ongoing discussion in the European Union on whether the indirect land use change effect of biofuels should be included in the assessment of biofuels' ability to reduce GHG emissions relative to conventional fuels. As we show, to be consistent, the leakage in other markets should be included, especially that of the fuel market because we show it is very likely to be greater than the leakage in the land market.

The remainder of the paper is organized as follows. The next section defines market leakage and the emissions savings effect of corn ethanol with and without consideration of petroleum by-products; and derives a rule to determine whether or not corn ethanol meets a sustainability standard. Data and procedures used to calibrate the numerical model (extended to oil, petroleum by-products, and the corn market) are presented in Section 3. In Section 4, we present our results. The last section provides some concluding remarks.

\section{MARKET LEAKAGE (INDIRECT OUTPUT USE CHANGE EFFECT) AND CHANGE IN GLOBAL CARBON EMISSIONS DUE TO ETHANOL}

At combustion, one gasoline-energy equivalent gallon (GEEG) of ethanol emits less carbon dioxide $\left(\mathrm{CO}_{2}\right)$ than one gallon of gasoline. Letting $e_{G}$ and $e_{E}$ denote kilograms of $\mathrm{CO}_{2}$ emitted per GEEG of ethanol and gasoline, the term

$\xi=\frac{e_{G}-e_{E}}{e_{G}}$

represents carbon savings of ethanol relative to gasoline; for example, a value $\xi=0.20$ means that one GEEG of ethanol emits 20 percent less carbon than the same quantity of gasoline. Embedded in expression (1) is the EPA's assumption that every GEEG of ethanol consumed replaces one gallon of gasoline.

However, because gasoline is but one of several joint products of crude oil processing, ethanol, in addition to gasoline, also replaces other petroleum byproducts, such as distillate fuel oil or kerosene; it is because gasoline and by-products quantities are linked through a fixed production coefficient. ${ }^{9}$ This is not reflected in EPA's estimates of $\mathrm{CO}_{2}$ savings of ethanol. The jointness in production implies a fixed proportion of gasoline and all other petroleum by-products. Denoting $\beta_{G}$ and $\beta_{B}$ as GEEGs of gasoline and by-products per barrel of crude oil, respectively, the ratio of the quantity of gasoline $(G)$ and by-products $(B)$ is given by

$$
\frac{G}{B}=\frac{\beta_{G}}{\beta_{B}}
$$

\footnotetext{
${ }^{9}$ We assume oil is not a substitute for other primary energy sources, such as coal or natural gas. Therefore, leakage estimates presented in this paper are a lower bound if one allows for imperfect substitutability between oil and other primary energy sources.
} 
Equation (2) implies that associated with one GEEG of gasoline are $\beta_{B} / \beta_{G}$ GEEGs of petroleum byproducts. Therefore, the $\mathrm{CO}_{2}$ savings of one GEEG of ethanol relative to one GEEG of gasoline and a corresponding quantity of the petroleum by-products are

$$
\theta=\frac{e_{G}+\frac{\beta_{B}}{\beta_{G}} e_{B}-e_{E}}{e_{G}+\frac{\beta_{B}}{\beta_{G}} e_{B}}
$$

where $e_{B}$ denotes $\mathrm{CO}_{2}$ emissions of a GEEG of byproducts. $^{10}$ The interpretation of equation (3) is analogous to that of equation (1). A comparison of equations (1) and (3) yields $\theta>\xi$. Intuitively, carbon savings of ethanol are expected to be higher when petroleum by-products are included; this is because in addition to reducing gasoline consumption, ethanol also reduces consumption of the by-products, thus effectively reducing more carbon.

The introduction of $E$ GEEGs of ethanol to the fuel market affects relative prices, and hence also global consumption of gasoline and the petroleum by-products. The change in relative prices results in higher oil consumption in the rest of the world (ROW), which runs afoul of the EPA's implicit assumption that one GEEG of ethanol replaces gasoline one-to-one. To measure the number of gallons of gasoline that are not replaced by ethanol, we define market leakage as

$L_{M}=\frac{\Delta G+E}{E}$

where $\Delta G<0$ denotes a reduction in global gasoline consumption due to the introduction of $E$ GEEGs of ethanol. We define market leakage (4) solely in terms of gasoline and ethanol; the presence of petroleum byproducts is implicitly embedded in the change in gasoline consumption, $\Delta G$. For example, a value of $L_{M}=0.7$ means that one GEEG of ethanol replaces only 0.3 gallons of gasoline.

When $E$ GEEGs of ethanol are placed on the market and consumed (we assume zero ethanol consumption initially), the change in $\mathrm{CO}_{2}$ emissions is given by ${ }^{11}$

\footnotetext{
10 In the numerical part of the paper, we show that $\theta=0.79$ if indirect land use change is not considered, and $\theta=0.65$ when this effect is taken into account.

11 Throughout the paper, we assume that ethanol policies are implemented only in the Home country. While this assumption greatly simplifies the theoretical analysis, it makes no difference to our qualitative results. It is because, in theory, one can always aggregate all countries producing biofuels into a Home country and treat the remaining countries as a Foreign country (as it is typically done in a partial equilibrium analysis). Because our numerical simulations are meant to illustrate and quantify our theoretical results, we follow the same principles and use the Unites States - world's largest ethanol producer - as an example. Even though we do not model biofuel policies in every single country that produces biofuels, we note that leakage estimates are more sensitive to elasticities than they are to fuel consumption/production shares. This suggests that, for a given set of elasticities, our leakage estimates would not change significantly if more than two countries were analyzed.
}

$\Delta$ in global $\mathrm{CO}_{2}=e_{E} E+e_{G} \Delta G+e_{B} \Delta B$

where $\Delta B$ denotes a change in global consumption of petroleum by-products.

$\begin{array}{ccc}\text { Relationship (2) implies } \Delta B=\left(\beta_{B} / \beta_{G}\right) \Delta G & \text { and } \\ \text { from } \quad \text { equation } & (3), \quad \text { we } & \text { have } \\ e_{E}=(1-\theta)\left[e_{G}+\left(\beta_{B} / \beta_{G}\right) e_{B}\right] . \quad \text { Substituting } & \text { these }\end{array}$ expressions into equation (5) and rearranging, obtains

$$
\begin{aligned}
& \Delta \text { in global } \mathrm{CO}_{2}= \\
& \underbrace{-\theta\left[e_{G}+\left(\beta_{B} / \beta_{G}\right) e_{B}\right] E}_{\begin{array}{c}
\text { reduction in emissions associated with } \\
\text { consumption of ethanol }
\end{array}}+\underbrace{\left[e_{G}+\left(\beta_{B} / \beta_{G}\right) e_{B}\right](E+\Delta G)}_{\begin{array}{c}
\text { change in emissions due to } \\
\text { market leakage }
\end{array}} \text { (6) }
\end{aligned}
$$

The first term on the right-hand side of equation (5) represents a reduction in carbon emissions due to $E$ GEEGs of ethanol relative to the same quantity of gasoline and corresponding by-products if ethanol replaced gasoline one-to-one. The second term represents a change in global carbon emissions - typically an increase - that occurs because of a change in the relative prices. To see this better, the term $E+\Delta G$ in equation (5) can be replaced by $E L_{M}$ (from equation (4)). Therefore, total carbon emissions per GEEG of ethanol, taking into account the market leakage effect, are

$$
\frac{(1-\theta)\left[e_{G}+\left(\beta_{B} / \beta_{G}\right) e_{B}\right] E+\left[e_{G}+\left(\beta_{B} / \beta_{G}\right) e_{B}\right] E L_{M}}{E}
$$

where the first term in the numerator of expression (7) represents carbon emissions of corn ethanol, assuming it replaces gasoline one-to one. With expression (7), we are in a position to determine the overall carbon savings of one GEEG of corn ethanol relative to one GEEG of gasoline and associated petroleum by-products. To do that, we reuse definition (3) by substituting the overall carbon savings of ethanol, $\left(1-\theta+L_{M}\right)\left[e_{G}+\left(\beta_{B} / \beta_{G}\right) e_{B}\right]$ (obtained by simplifying expression (7)) for the term $e_{E}$ in equation (3), to obtain

$$
\frac{e_{G}+\left(\beta_{B} / \beta_{G}\right) e_{B}-\left(1-\theta+L_{M}\right)\left[e_{G}+\left(\beta_{B} / \beta_{G}\right) e_{B}\right]}{e_{G}+\left(\beta_{B} / \beta_{G}\right) e_{B}}
$$

$=\theta-L_{M}$

This result is in line with the finding of Stoft (2010).

Expression (8) suggests that corn ethanol results in a reduction in global carbon emissions if and only if $\theta-L_{M}>0$; that is, the emissions savings effect of a biofuel has to outweigh the indirect output use effect. For instance, if $\theta=0.8$ and $L_{M}=0.7$, then net savings of corn ethanol relative to gasoline and corresponding byproducts are only 10 percent.

Finally, the quantity (8) can be used to determine whether corn ethanol meets a pre-determined 
sustainability standard. $^{12}$ This entails determining whether

$$
\theta-L_{M}>\text { sustainabilty standard }
$$

If the statement (9) holds, corn ethanol meets the standard.

\section{DATA}

We use the numerical model detailed in Cui et al. (2011), but calibrate it to a different set of biofuel policies, namely: a binding mandate combined with a blender's tax credit, an ethanol production subsidy, and a feedstock (corn) production subsidy. All baseline data, their primary sources, or formulas are presented in the Appendix. All relevant data are converted into gasolineenergy equivalents to consistently model the linkages in the fuel market.

\section{Calibration}

Biofuel policies have historically caused ethanol production in the United States (Drabik 2011). Although the ethanol mandate and blender's tax credit have perhaps been most influential in determining the quantity of ethanol consumed in the United States, the ethanol industry has also benefited from ethanol and corn production subsidies. The U.S. ethanol consumption in 2009 amounted to 11.04 bil. gallons, which represents a 6 percent energy share in total U.S. gasoline fuel consumption. The ethanol blender's tax credit of $\$ 0.498 /$ gallon consists of the federal part, \$0.45/gallon, and the state part, which averaged \$0.048/gallon in 2009 (Koplow 2009). The ethanol production subsidy calculated from Koplow (2009) is \$0.14/gallon in 2008. We assume the same level of the subsidy in 2009.

Corn subsidies in the Unites States totaled \$3.79 bil. in 2009 (Environmental Working Group). ${ }^{13}$ Of the total, $\$ 2.00$ bil. were decoupled subsidies. Following Sumner (2006), we assume a coefficient of 0.25 as the degree to which decoupled subsidies are actually coupled. Total production subsidies for corn is computed as follows: $0.25 \times 2.00$ bil. $+(\$ 3.79$ bil. $-\$ 2.00$ bil. $)=$ $\$ 2.29$ bil. This translates to a subsidy of $\$ 0.17 /$ bushel.

The U.S. fuel tax for gasoline was $\$ 0.49$ /gallon in 2009 (American Petroleum Institute). This includes the federal and state excise taxes as well as other taxes. The average tax on the petroleum by-products we consider equals 33 percent of the gasoline tax.

Following the analysis in de Gorter and Just (2009b), we calibrate the model to a binding mandate

\footnotetext{
12 We are grateful to a reviewer for pointing out that the threshold used in inequality (9) is not the same as the EPA threshold; in fact, it is more general. Because we calculate carbon savings of ethanol viz-a-viz gasoline and corresponding petroleum by-products, we cannot use the EPA's standard for comparison, as it relates strictly to gasoline. It is to be noted, however, that this does not affect the ensuing results. It is because had the EPA recognized the additional carbon savings from replacing some petroleum by-products, it would have very likely increased the threshold. This would make it even less likely for corn ethanol to pass the sustainability test.

${ }^{13} \mathrm{http}: / /$ farm.ewg.org/progdetail.php?fips $=00000$ \&progcode $=$ corn
}

(and other policies described above). In this case, the price of fuel (a mix of ethanol and gasoline) is equal to the weighted average of ethanol and gasoline prices adjusted for the fuel tax and the tax credit. ${ }^{14}$ Corn and ethanol prices are linked through a zero profit condition for ethanol production; similarly are linked the prices of oil, gasoline, and petroleum by-products.

In the feedstock (corn) market, we explicitly model the market effects of the co-product of ethanol production (Dried Distillers Grains with Solubles, DDGS). (See Drabik 2011 for details on these effects). Following Hoffman and Baker (2011), we assume 81 percent of DDGS is consumed domestically and the rest is exported.

Our numerical model uses demand and supply curves that exhibited constant price elasticities; this enables us to capture potential non-linear effects due to introduction of ethanol in the analyzed markets. The elasticities values are adopted from other studies (Gardner 2007; Hamilton 2009; and Cui et. al. 2011) and are presented in the Appendix. Owing to the lack of econometric estimates, we assume the demand for petroleum by-products has the same elasticity as the demand for fuel. We assume the supply elasticity of oil in the ROW is 0.15 . We do so to obtain a reasonable estimate of demand elasticity for oil in the ROW, -0.29 (this demand elasticity is consistent with the results of a recent meta-analysis by Havránek et al. 2012), while imposing that the elasticity of oil import supply facing the United States is 3.00 - a value used in Cui et al. (2011).

\section{Carbon emissions}

An oil refinery produces a number of petroleum products, of which gasoline represents 46.1 percent (Table 1 ). The implied volume of gasoline obtained from one barrel of oil (42 gallons) is thus 0.461 x $42=19.362$ gallons. The second column in Table 1 presents the implied volumes for other petroleum products as well. The total number of gallons (44.772) of all petroleum products obtained from one barrel of crude oil exceeds 42 . This is known as the oil processing gain (6.6 percent in 2009), and it occurs because the density of oil products changes relative to the density of oil during the refining process. The third column in Table 1 gives shares of individual petroleum by-products (exclusive of gasoline) in the total volume of by-products ( 25.41 gallons).

The actual yield of gasoline per barrel of crude oil differs from the (theoretical) one reported in the second column of Table 1. There are two reasons for this. First, the volume of 19.362 gallons does not take into account the processing gains. It is not clear, however, how the processing gains are actually distributed among various oil products. Second, before gasoline is sold at retail pump stations, special additives (other than ethanol) are mixed with gasoline to enhance its properties. These additives are produced from petroleum by-products. Hence, some volume of the by-products is reshuffled to

\footnotetext{
${ }^{14}$ If the tax credit was the binding policy, the fuel price would be equal to the sum of the gasoline price and the fuel tax.
} 
gasoline, thus making its effective volume per barrel of oil be more than 19.362 gallons.

We calculated the actual number of gallons of gasoline per barrel of oil as follows. The total fuel consumption in the Unites States in 2009 amounted to 134.74 bil. gallons (physical volume). This includes

Table 1 Oil products and their carbon emissions

\begin{tabular}{|c|c|c|c|c|c|c|}
\hline & $\begin{array}{r}\text { Refinery } \\
\text { yield } \\
\text { (share) }^{\mathrm{a}} \\
\end{array}$ & $\begin{array}{r}\text { Gallons/ } \\
\text { barrel }\end{array}$ & $\begin{array}{r}\text { Share in } \\
\text { by- } \\
\text { products }\end{array}$ & $\begin{array}{r}\text { Adjusted } \\
\text { gallons/ } \\
\text { barrel } \\
\end{array}$ & $\begin{array}{l}\mathrm{kgCO}_{2} / \\
\text { gallon }\end{array}$ & $\begin{array}{r}\text { Total kg } \\
\mathrm{CO}_{2} / \text { barrel }\end{array}$ \\
\hline Gasoline & 0.461 & 19.362 & & 21.483 & 8.91 & 191.42 \\
\hline Distillate fuel oil & 0.269 & 11.298 & 0.445 & 10.355 & 10.15 & 105.10 \\
\hline Kereosene type jet fuel & 0.093 & 3.906 & 0.154 & 3.580 & 9.57 & 34.26 \\
\hline Residual fuel oil & 0.040 & 1.680 & 0.066 & 1.540 & 11.79 & 18.15 \\
\hline Kerosene & 0.001 & 0.042 & 0.002 & 0.038 & 9.76 & 0.38 \\
\hline Liquid refinery gases & 0.041 & 1.722 & 0.068 & 1.578 & 6.00 & 9.47 \\
\hline Still gas & 0.044 & 1.848 & 0.073 & 1.694 & 9.17 & 15.53 \\
\hline Petroleum coke & 0.053 & 2.226 & 0.088 & 2.040 & 14.65 & 29.89 \\
\hline Finished aviation gasoline & 0.001 & 0.042 & 0.002 & 0.038 & 8.32 & 0.32 \\
\hline $\begin{array}{l}\text { Naptha for petrochemical } \\
\text { feedstock use }\end{array}$ & 0.013 & 0.546 & 0.021 & & & \\
\hline $\begin{array}{l}\text { Other oils for petrochemical } \\
\text { feedstock use }\end{array}$ & 0.008 & 0.336 & 0.013 & & & \\
\hline Special naphthas & 0.002 & 0.084 & 0.003 & & & \\
\hline Lubricants & 0.010 & 0.420 & 0.017 & & & \\
\hline Waxes & 0.001 & 0.042 & 0.002 & & & \\
\hline Asphalt and road oil & 0.024 & 1.008 & 0.040 & & & \\
\hline Miscellaneous products & 0.005 & 0.210 & 0.008 & & & \\
\hline Total & 1.066 & 44.772 & & $20.864^{c}$ & & 404.52 \\
\hline $\begin{array}{l}\text { Subtotal for by-products } \\
\text { (excluding gasoline) }\end{array}$ & & 25.410 & & 23.289 & & \\
\hline
\end{tabular}

Note:

${ }^{a}$ http://www.eia.gov/dnav/pet/pet_pnp_pct_dc_nus_pct_a.htm

${ }^{\mathrm{b}}$ http://205.254.135.7/oiaf/1605/coefficients.html

c Denotes the sum of petroleum by-products in this column.

gasoline, additives, and ethanol. ${ }^{15}$ The ethanol consumption was 11.04 bil. gallons and imports of additives (not produced from the oil processed in the United States) were 10.73 bil. gallons. Thus, the quantity of gasoline (inclusive of additives) produced domestically is equal to $134.74-11.04-10.73=112.98$ bil. gallons. Finally, the actual yield of gasoline per barrel of crude oil, 21.483 gallons, is obtained by dividing the quantity of gasoline produced in the United States and the quantity of oil processed in 2009, 5.26 bil. barrels.

As we are not able to apportion the processing gains to individual petroleum products, nor are we able to determine how much of each petroleum by-product was used to produce gasoline additives, we adjust the volumes of petroleum by-products per barrel of oil as follows. The total volume of the by-products is 23.289 gallons (=44.772 - 21.483). Then, we multiply this volume by the shares reported in the third column in Table 1. Thus, for example, the adjusted volume of distillate fuel oil is equal to $0.445 \times 23.289=10.355$

\footnotetext{
${ }^{15}$ We endogenize imports of additives by fixing the ratio of imports of additives to domestic gasoline production at its baseline value.
}

gallons. We calculate the adjusted volumes only for petroleum by-products that get combusted.

The fifth column shows how much $\mathrm{CO}_{2}$ is released when one gallon of a petroleum product is combusted. The last column of Table 1 gives total $\mathrm{CO}_{2}$ emissions by which each product contributes to a barrel of oil. For example, for gasoline it is $21.483 \times 8.91=191.42$ $\mathrm{kg} / \mathrm{barrel}$. The sum of the values in the last column then gives total $\mathrm{CO}_{2}$ emissions of a barrel of oil at combustion, $404.52 \mathrm{~kg}$.

But $404.52 \mathrm{~kg} \mathrm{CO}$ per barrel of oil is an under estimate because it ignores other emissions, for instance, those related to drilling of oil. We thus need to determine $\mathrm{CO}_{2}$ emissions of crude oil corresponding to its life-cycle analysis (LCA). To do that, we use the values given in Table 2. Total LCA (i.e., well-to-wheels) carbon emissions of gasoline are estimated to be $10.803 \mathrm{~kg} /$ gallon; this translates into $21.483 \times 10.803=$ $232.07 \mathrm{~kg} /$ barrel. As much as 80 percent of all carbon emissions of gasoline are released at combustion (i.e., tank-to-wheels). We assume this ratio applies also to other petroleum by-products. Thus, we calculate LCA emissions of petroleum by-products as 213.10/0.8 = $264.89 \mathrm{~kg} /$ barrel, where the value of 213.10 represents the 
Table 2 Emission intensities of gasoline, petroleum by-products, and corn ethanol

\begin{tabular}{|c|c|c|c|c|}
\hline Variable & Symbol & Value & Unit & Source \\
\hline Gasoline well-to-tank $\mathrm{CO}_{2} \mathrm{e}$ emissions & $\mathrm{G}_{\mathrm{WT}}$ & 19,200 & $\begin{array}{l}\text { grams/ } \\
\text { mmBTU }\end{array}$ & $\mathrm{EPA}^{\mathrm{a}, \mathrm{b}}$ \\
\hline Gasoline well-to-wheels $\mathrm{CO}_{2} \mathrm{e}$ emissions & $\mathrm{G}_{\mathrm{WW}}$ & 98,205 & $\begin{array}{l}\text { grams/ } \\
\text { mmBTU }\end{array}$ & $\mathrm{EPA}^{\mathrm{c}}$ \\
\hline Gasoline tank-to-wheels $\mathrm{CO}_{2} \mathrm{e}$ emissions & $\mathrm{G}_{\mathrm{TW}}$ & 79,005 & $\begin{array}{l}\text { grams/ } \\
\text { mmBTU }\end{array}$ & $\mathrm{G}_{\mathrm{TW}}=\mathrm{G}_{\mathrm{WW}}-\mathrm{G}_{\mathrm{WT}}$ \\
\hline mmBTUs per gallon of gasoline & $\sigma$ & 0.11 & $\begin{array}{l}\text { mmBTU/ } \\
\text { gallon }\end{array}$ & $\begin{array}{r}\text { National Renewable Energy } \\
\text { Laboratories (2008) }\end{array}$ \\
\hline $\begin{array}{l}\text { Gasoline well-to-tank } \mathrm{CO}_{2} \mathrm{e} \text { emissions (in } \\
\mathrm{kg} \text { /gallon) }\end{array}$ & $\mathrm{G}_{\mathrm{WT}}^{\prime}$ & 2.11 & $\begin{array}{l}\mathrm{kg} \mathrm{CO} \mathrm{C}_{2} \mathrm{e} / \\
\text { gallon }\end{array}$ & $\mathrm{G}_{\mathrm{WT}}^{\prime}=\mathrm{G}_{\mathrm{WT}}{ }^{*} \sigma / 1000$ \\
\hline $\begin{array}{l}\text { Gasoline well-to-wheels } \mathrm{CO}_{2} \text { e emissions } \\
\text { (in kg/gallon) }\end{array}$ & $\mathrm{G}_{\mathrm{WW}}^{\prime}$ & 10.803 & $\begin{array}{l}\mathrm{kg} \mathrm{CO} 2 \mathrm{e} / \\
\text { gallon }\end{array}$ & $\mathrm{G}_{\mathrm{WW}}^{\prime}=\mathrm{G}_{\mathrm{WW}}{ }^{*} \sigma / 1000$ \\
\hline $\begin{array}{l}\text { Gasoline tank-to-wheels } \mathrm{CO}_{2} \mathrm{e} \text { emissions } \\
\text { (in kg/gallon) }\end{array}$ & $\mathrm{G}_{\mathrm{TW}}^{\prime}$ & 8.69 & $\begin{array}{l}\mathrm{kg} \mathrm{CO} 2 \mathrm{e} / \\
\text { gallon }\end{array}$ & $\mathrm{G}_{\mathrm{TW}}^{\prime}=\mathrm{G}_{\mathrm{TW}}{ }^{*} \sigma / 1000$ \\
\hline $\begin{array}{l}\text { Tank-to-wheels/well-to-wheels } \\
\text { (=combustion/total emissions) ratio }\end{array}$ & $\kappa$ & 0.80 & & $\kappa=\mathrm{G}_{\mathrm{TW}}^{\prime} / \mathrm{G}_{\mathrm{WW}}^{\prime}$ \\
\hline $\begin{array}{l}\mathrm{CO}_{2} \text { emissions of gasoline per barrel of oil, } \\
\text { including LCA }\end{array}$ & $\mu_{1}$ & 232.07 & kg/barrel & $\mu_{1}=\beta_{G}{ }^{*} G_{W W}^{\prime}$ \\
\hline $\begin{array}{l}\mathrm{CO}_{2} \text { emissions of petroleum by-products at } \\
\text { combustion }\end{array}$ & $\mu_{2}$ & 213.10 & kg/barrel & $\begin{array}{r}\text { Sum of the values in the last } \\
\text { column in Table } 1 \text { exclusive of } \\
\text { gasoline }\end{array}$ \\
\hline $\begin{array}{l}\mathrm{CO}_{2} \text { emissions of petroleum by-products } \\
\text { (per barrel), including LCA }\end{array}$ & $\mu_{3}$ & 264.89 & kg/barrel & $\mu_{3}=\mu_{2} / \kappa$ \\
\hline $\begin{array}{l}\mathrm{CO}_{2} \text { emissions of petroleum by-products } \\
\text { (per gallon), including LCA }\end{array}$ & $\mu_{4}$ & 12.696 & kg/gallon & $\begin{array}{r}\mu_{4}=\mu_{3} / \text { sum of adjusted } \\
\text { gallons/barrel of petroleum by- } \\
\text { products from Table } 1\end{array}$ \\
\hline $\begin{array}{l}\text { Total } \mathrm{CO}_{2} \text { emissions per barrel of oil } \\
\text { Carbon savings of corn ethanol relative to } \\
\text { gasoline }\end{array}$ & $\mu_{\mathrm{T}}$ & 496.96 & kg/barrel & $\mu_{\mathrm{T}}=\mu_{1}+\mu_{3}$ \\
\hline Excluding land use change & $\xi_{52}$ & 0.52 & & RFA $^{d}$ \\
\hline Including land use change & $\xi_{21}$ & 0.21 & & $\mathrm{EPA}^{\mathrm{c}}$ \\
\hline \multicolumn{5}{|l|}{$\begin{array}{l}\text { Carbon savings of corn ethanol relative to } \\
\text { gasoline \& by-products }\end{array}$} \\
\hline Excluding land use change & $\theta_{52}$ & 0.79 & & $\begin{array}{r}\theta_{52}=\left(\mathrm{G}_{\mathrm{wW}}^{\prime}+\left(\beta_{\mathrm{B}} / \beta_{\mathrm{G}}\right) * \mu_{4}-\mathrm{z}_{52}\right) / \\
\left(\mathrm{G}_{\mathrm{ww}}^{\prime}+\left(\beta_{\mathrm{B}} / \beta_{\mathrm{G}}\right) * \mu_{4}\right)\end{array}$ \\
\hline Including land use change & $\theta_{21}$ & 0.65 & & $\begin{array}{r}\theta_{21}=\left(\mathrm{G}_{\mathrm{WW}}^{\prime}+\left(\beta_{\mathrm{B}} / \beta_{\mathrm{G}}\right)^{*} \mu_{4}-\mathrm{z}_{21}\right) / \\
\left(\mathrm{G}_{\mathrm{wW}}^{\prime}+\left(\beta_{\mathrm{B}} / \beta_{\mathrm{G}}\right) * \mu_{4}\right)\end{array}$ \\
\hline $\begin{array}{l}\text { Corn ethanol carbon emissions if 52\% } \\
\text { reduction relative to gasoline }\end{array}$ & $\mathrm{Z}_{52}$ & 5.19 & $\begin{array}{l}\mathrm{kg} \mathrm{CO} 2 \mathrm{e} / \\
\mathrm{GEEG}\end{array}$ & $\mathrm{z}_{52}=\left(1-\xi_{52}\right) \mathrm{G}_{\mathrm{WW}}^{\prime}$ \\
\hline $\begin{array}{l}\text { Corn ethanol carbon emissions if } 21 \% \\
\text { reduction relative to gasoline }\end{array}$ & $\mathrm{Z}_{21}$ & 8.53 & $\begin{array}{l}\mathrm{kg} \mathrm{CO} 2 \mathrm{e} / \\
\mathrm{GEEG}\end{array}$ & $\mathrm{z}_{21}=\left(1-\xi_{21}\right) \mathrm{G}_{\mathrm{WW}}^{\prime}$ \\
\hline
\end{tabular}

Note:

a nepis.epa.gov/Exe/ZyPURL.cgi?Dockey=P1006DXP.txt (Table 2.5-8)

b mmBTUs = million British Thermal Units

c http://www.epa.gov/otaq/renewablefuels/420r10006.pdf (page 467 and Figure 2.6-1)

d http://renewablefuelsassociation.cmail1.com/T/ViewEmail/y/78B3C6C380747C63

total emissions (at combustion) of petroleum by-products per barrel of oil. (It is the sum of the values in the last column in Table 1 exclusive of gasoline). We calculate carbon emissions of petroleum by-products by dividing carbon emissions of the by-products per barrel of oil (264.89 kg) by the sum of adjusted gallons/barrel of petroleum by-products from the fourth column in Table 1 (20.864 gallons); thus, we arrive at $12.696 \mathrm{~kg} / \mathrm{gallon}$. Finally, the total carbon emissions per barrel of oil are given by the sum of gasoline and by-products emissions, that is, $232.07+264.89=496.96 \mathrm{~kg} /$ barrel.

In the numerical simulations, we assume two scenarios for the carbon savings of corn ethanol relative to gasoline. First, corn ethanol emits 52 percent less carbon emissions relative to gasoline it is supposed to replace. This estimate does not take into account the emissions due to land use change due to biofuels. When emissions from land use change are included, the relative savings of corn ethanol reduce to 21 percent (EPA 2010). ${ }^{16}$ It is important to note, however, that these savings relate only to gasoline and ignore other potential savings due to petroleum by-products. Thus, to obtain estimates of the total carbon savings of ethanol relative to gasoline and corresponding petroleum by-products, we use equation (3) and values reported in Table 2 to arrive

\footnotetext{
16 http://www.epa.gov/otaq/renewablefuels/420r10006.pdf (page 467 and Figure 2.6-1)
} 
at carbon savings of 79 and 65 percent for the case when emissions from land use change are excluded and included, respectively. Intuitively, the carbon savings should be higher, because one gasoline-energy equivalent gallon of ethanol not only replaces gasoline, but also a corresponding quantity of petroleum by-products.

\section{RESULTS}

In this section, we empirically illustrate our theoretical findings. We analyze market effects of three biofuel policies: an ethanol blender's tax credit, a consumption mandate, and their combination. (See Drabik 2011 for the underlying economics of individual policies). The motivation for choosing the three policies is the fact that they have been used in the United States in different periods of the biofuel era (first, the tax credit alone; then coupled with the mandate; and currently only the mandate as the tax credit for corn ethanol has been abandoned). Moreover, other countries (e.g., the European Union) also use various policies.

To be able to compare the effects of individual policies, we hold ethanol consumption constant and equal to its baseline level (11.04 bil. gallons or 7.63 bil. GEEGs). In all simulations, we set ethanol and corn production subsidies to zero. For ease of comparison, we express all prices and quantities in energy-equivalent terms.

The first column in Table 3 presents a market outcome under no biofuel policy (i.e., ethanol use is not mandated, and no blender's tax credit is provided). In this situation, the free market price of ethanol (\$1.82/GEEG) is too low to generate any ethanol production. ${ }^{17}$ We take the values reported in the first column as benchmark values to be used for estimation of the magnitude of market leakage associated with individual ethanol policies.

In the second column, we present market effects of a blender's tax credit alone. To achieve the predetermined level of ethanol consumption, a \$0.87/gallon tax credit is required. ${ }^{18}$ Notice that this tax credit is almost twice as high as the one actually used in 2009. The competition among fuel blenders for the tax credit bids the ethanol price up by $\$ 0.99 /$ GEEG relative to the no policy scenario. Ethanol consumption replaces some gasoline, thus reducing the world demand for oil. As a result, the oil market price decreases (net) by $\$ 0.95 /$ barrel, as does the gasoline price (down by $\$ 0.27 /$ gallon). The reduction in the oil price is mitigated by an increase in the market price of petroleum products,

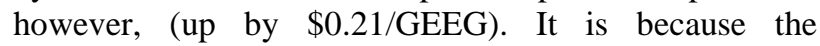
reduction in global oil production results in a decrease in the production of petroleum by-products (they are produced from crude oil through a fixed-coefficient technology) while demand for them remains unchanged.

As predicted by theory, the reduction in the oil price under the mandate alone in the third column

\footnotetext{
${ }^{17}$ This occurs because the intersection of the corn supply and demand curves (which corresponds to the intercept of the ethanol supply curve) is above the free market price of ethanol (Drabik 2011).

${ }^{18}$ This corresponds to $\$ 1.27 /$ GEEG of ethanol.
}

(\$-1.08/barrel) is greater than the reduction under the combination of policies in the fourth column (\$-1.01/barrel). ${ }^{19}$ Ethanol price increase is the same across all three policies, however, as they all share the same level of ethanol consumption. Although the global oil consumption due to the introduction of ethanol decreases under each policy between 0.07 to 0.08 bil. barrels, a lower oil price induces higher oil consumption in the ROW (between 0.09 to 0.11 bil. barrels).

Given that global oil consumption decreases under each policy, a question arises whether ethanol (in energy equivalent) replaces gasoline one-to-one as assumed by the EPA in constructing the sustainability standard for ethanol. The answer is no, and Table 4 shows how much gasoline is displaced (as opposed to replaced) by ethanol.

The first row in Table 4, entitled Most plausible parameters, corresponds to the values presented in Table $3 .^{20}$ For example, the value 0.812 under the tax credit policy means that introduction of 1 GEEG of corn ethanol in the United States results in a global increase in fuel consumption by 0.812 GEEGs (see also equation (4)). ${ }^{21,22}$ Notice that if ethanol replaced gasoline one-t one, then the change in global fuel consumption should be zero. Under the tax credit, one GEEG of ethanol replaces only $1-0.812=0.188$ gallons of gasoline .

The remaining rows in Table 4 show how sensitive the market leakage due to a biofuel policy is to the assumed elasticities of supply and demand curves in the world fuel market. ${ }^{23}$ The changes in elasticities in the second, third, and forth row are self-explanatory. In the scenario entitled Inelastic fuel demand, we assume the elasticity of U.S. demand for fuel to be -0.09 . This value corresponds to the average short run elasticity reported by Havránek et al. (2012). In the last scenario, Reversed yields of gasoline and petroleum by-products, we assume, similarly to Cui et al. (2011), that there are no imports of gasoline additives. This implies 23.52 and 21.25 gallons of gasoline and petroleum by-products, respectively per barrel of crude oil.

All scenarios exhibit stable and high levels of market leakage both within and across biofuel policies. ${ }^{24}$

\footnotetext{
${ }^{19}$ When the tax credit is combined with the mandate, the tax credit is equal to $\$ 0.498$ /gallon.

${ }^{20}$ We take these elasticities from well known and respected papers in the agricultural and energy economics profession.

21 More specifically, the change in global fuel consumption is given by the sum of ethanol consumption and the change in global gasoline consumption. The former amounted to 7.63 bil. GEEGs (Table 3) and the latter is equal to $21.483 \times(-0.07)=-1.43$ bil. GEEGs, where 21.483 denotes GEEGs of gasoline per barrel of oil, and -0.07 denotes the reduction in global oil consumption from Table 3 . Thus, the change in global fuel consumption is equal to $7.63+(-1.43)=6.20$ bil. GEEGs (the rest of the world consumes only gasoline). One GEEG of ethanol is then associated with an increase in fuel consumption of 6.20/7.63= 0.812 GEEGs.

${ }^{22}$ For comparison, Chen and Khanna (2012), report a leakage in the global gasoline market (under a mandate) of 50.1 percent; in Drabik et al. (2010), the market leakage varies between 60-65 percent; and in Drabik and de Gorter (2010) between 64-79 percent.

23 The coefficients of variations corresponding to "Tax credit", "Mandate", and "Mandate \& tax credit" are 6.7, 8.1, and 7.3 percent, respectively. The coefficient of variation for all market leakage estimates in Table 4 is 7.1 percent.

${ }^{24}$ The stability of leakage estimates across policy instruments stems from the fact that we compare for the same level of ethanol
} 
(An exception, perhaps, is the case of very elastic oil supply relative to oil demand in the ROW. Yet, market leakage is quite high, above 60 percent). In summary, one GEEG of ethanol is empirically found to replace between 0.185 to 0.371 gallons of gasoline.

Even if world crude oil consumption decreases in response to consumption of ethanol, it does not necessarily mean that global carbon emissions decrease as well. Intuitively, this happens because ethanol is not a carbon-free replacement of gasoline. Recall that the EPA requires that corn-ethanol emits at least 20 percent less carbon relative to gasoline it is assumed to replace.

We estimate the actual carbon savings of ethanol relative to gasoline and corresponding petroleum byproducts in Table 5; all values are calculated by taking the difference between the emissions savings effect of ethanol relative to gasoline and petroleum by-products and the market leakage effect reported in Table 4 (see equation (8)). The actual carbon savings of corn ethanol are calculated under two situations. In the first situation, we exclude emissions form indirect land use change on total carbon emissions of ethanol, while in the second situation we include the indirect land use change effect. Because the latest EPA's ruling does include indirect land use change emissions, the latter set of results is likely to be more relevant from a policy point of view.

To illustrate our results, consider first the actual carbon savings of ethanol under the Most plausible parameters case and tax credit, excluding emissions from land use change. The corresponding value of -2.3 percent is obtained using expression (8) and is equal to a difference between 0.789 [x100\%] and 0.812 [x100\%], where the former value is the carbon emissions savings effect of corn ethanol relative to gasoline and corresponding petroleum by-products (when emissions from land use change are excluded), and the latter value is the market leakage effect from Table 4. The interpretation of the carbon savings of $-2.3 \%$ is straightforward: corn ethanol increases carbon emissions relative to gasoline and petroleum by-products by 2.3 percent. Two effects cause this result. First, we have shown that corn ethanol fails to replace gasoline one-toone. Instead, the rate of replacement is much lower (19 to 37 percent), meaning that the carbon reducing effects of ethanol are difficult to materialize. Second, ethanol does not reduce 100 percent carbon emissions relative to gasoline and petroleum by-products. In other words, a dirty fuel is replaced by a less dirty fuel.

Notice, however, that global carbon emissions decline when the ethanol use is mandated (first row and second column in Table 5). The reduction is only marginal, however, because one GEEG of ethanol reduces only 0.2 percent carbon emissions relative to gasoline and by-products. A more significant reduction (16 percent) is achieved under the mandate and very elastic oil supply curve in the ROW (fourth scenario). Nonetheless, corn ethanol does not meet the EPA

consumption. As a result, the decrease in the domestic fuel price is similar across policy instruments, as is the decrease in the market price of gasoline. sustainability standard of 20 percent (see also footnote 12).

When emissions from land use change are taken into account, the carbon saving potential of corn-ethanol relative to gasoline declines significantly. For example, under the Most plausible parameters scenario, corn ethanol emits 13.5 - 16 percent more carbon than gasoline and corresponding petroleum by-products. In conclusion, our results suggest that it is very unlikely that the U.S. corn ethanol meets the 20 percent sustainability standard imposed by the EPA.

Such a conclusion warrants some discussion as to under which conditions this result holds. We therefore analyze the threshold market leakage below which our conclusion would not hold true. Suppose for a moment that the EPA's sustainability standard for corn ethanol is a $20 \%$ carbon emissions reduction relative to gasoline and corresponding petroleum by-products (albeit the EPA does not consider the by-products). Then rearranging condition (9), the threshold market leakage must satisfy max $L_{M}<\theta$-sustainabilty standard . To obtain a conservative estimate for this threshold, we set $\theta=0.79$ (see Table2) which corresponds to corn ethanol carbon savings relative to gasoline and corresponding petroleum by-products and ignores the iLUC effect. So for given values, our conclusion does not hold, if market leakage is less than $59 \%$. To be more realistic, however, we should consider $\theta=0.65$ (Table 2) which takes into account the iLUC effect. As a result, the threshold market leakage falls to $45 \%$. But this is not the final estimate yet because as we explain in footnote 12, the sustainability standard that recognizes ethanol's savings not only relative to gasoline but also relative to by-products would be higher, hence further reducing the threshold market leakage. In summary, for the market leakage estimates provided in Table 4, it is safe to say that our key conclusion that the U.S. corn ethanol does not meet the EPA's sustainability standard holds.

But the literature provides a range of magnitudes for fuel market leakage that differ from ours. ${ }^{25}$ For example, Chen and Khanna (2012) find a leakage central value of $50 \%$ (with a range of $39 \%-68 \%$ ) and Rajagopal and Plevin (2013) a range of 30-70\%. While the low extreme (and hence less likely) values of these estimates make our conclusion discussable, the central estimates support it.

\section{CONCLUSION}

Leakage is a measure of the ineffectiveness of an environmental policy and is frequently discussed in the context of combating global climate change. We develop an analytical framework to analyze not only leakage due to alternative biofuel policies, namely consumption subsidies and mandates (and their combination), but also to determine whether a biofuel meets a pre-determined sustainability standard.

\footnotetext{
${ }^{25}$ The differences most likely stem from assuming different elasticities; modeling the mandate in a different way than we do (Chen and Khanna 2012); and using a different model structure.
} 
Whether or not consumption of biofuels results in an increase in global GHG emissions depends on two factors. First, the market leakage effect determines the actual rate by which a biofuel replaces a fossil fuel. Our sensitivity analyses show that one gasoline-energy equivalent gallon of ethanol replaces only 0.19 to 0.37 gallons of gasoline. Second, the emissions savings effect of a biofuel determines how much cleaner the biofuel is relative to the fossil fuel it is assumed to replace. In theory, global GHG emissions could decrease due to biofuel policies even if the biofuel does not replace the fossil fuel one-to-one, provided that the biofuel has significantly lower GHG emissions than the fossil fuel.

We find that the U.S. corn ethanol is unlikely to meet the EPA's sustainability standard not only when the indirect land use change effect of biofuel is considered, but more importantly, also when this effect is not taken into account. Recognizing the presence of carbon leakages of biofuel policies in both the fuel and land markets, we find that one gasoline energy-equivalent gallon of ethanol could emit as much as 16 percent more carbon than one gallon of gasoline.

The empirical evidence presented in this paper suggests leakage from biofuel policy is significant. Leakage from biofuels policies is difficult to address in policy design because a mandate does not help much due to international leakage overriding a potential negative domestic leakage. Leakage from biofuel policies is also a special problem from a policy standpoint because, unlike with leakage in a cap and trade or REDD scheme, the problem is not always solved by having all countries adopt a biofuels policy. The reason is that all leakage will be "autarky" leakage (i.e., all domestic) but this will likely result in little savings compared to the case if the United States was the only country with the biofuels policy.

Although we focus on the U.S. corn ethanol, the qualitative results of our study are also applicable to the ongoing discussion in the European Union on whether the indirect land use change effect of biofuels should be included in the assessment of biofuels' ability to reduce greenhouse gas emissions relative to conventional fuels. Future research in this area should analyze the fuel market leakages due biofuel policies of not only one country, but of the group of the largest biofuel consuming countries.

Acknowledgments: We are grateful to two anonymous reviewers and the editor of this journal for their valuable comments. All remaining errors are ours. This project was supported by the National Research Initiative of the National Institute of Food and Agriculture, US Department of Agriculture (USDA), Grant \#121-8520 and by the Cornell University Agricultural Experiment Station federal formula funds, Project No. NYC-1217433 received from Cooperative State Research, Education, and Extension Service, USDA. Any opinions, findings, conclusions, or recommendations expressed in this publication are those of the authors and do not necessarily reflect the view of the USDA.

Table 3 Market effects of a biofuel tax credit and mandate relative to no ethanol production

\begin{tabular}{|c|c|c|c|c|}
\hline \multirow[t]{2}{*}{ 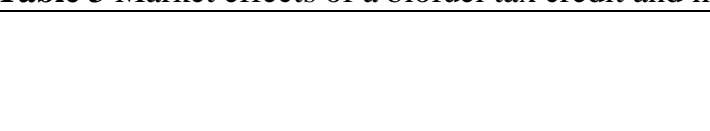 } & \multirow[t]{2}{*}{ No policy } & Tax credit & Mandate & $\begin{array}{r}\text { Mandate \& } \\
\text { tax credit }\end{array}$ \\
\hline & & \multicolumn{3}{|c|}{ Difference relative to no policy } \\
\hline Oil price (\$/barrel) & 61.98 & -0.95 & -1.08 & -1.01 \\
\hline Gasoline price (\$/GEEG) & 2.04 & -0.27 & -0.31 & -0.29 \\
\hline Ethanol price (\$/GEEG) & 1.82 & 0.99 & 0.99 & 0.99 \\
\hline Fuel price (\$/GEEG) & 2.53 & -0.27 & -0.24 & -0.26 \\
\hline $\begin{array}{l}\text { U.S. market price of petroleum by-products } \\
\text { (\$/GEEG) }\end{array}$ & 1.54 & 0.21 & 0.24 & 0.22 \\
\hline $\begin{array}{l}\text { U.S. consumer price of petroleum by-products } \\
\text { (\$/GEEG) }\end{array}$ & 1.71 & 0.21 & 0.24 & 0.22 \\
\hline U.S. gasoline consumption (billion GEEGs) & 116.57 & -3.47 & -3.95 & -3.68 \\
\hline U.S. fuel additives (billion GEEGS) & 11.07 & -0.33 & -0.38 & -0.35 \\
\hline U.S. ethanol consumption (billion GEEGs) & 0.00 & 7.63 & 7.63 & 7.63 \\
\hline U.S. fuel consumption (billion GEEGs) & 127.65 & 3.83 & 3.30 & 3.60 \\
\hline $\begin{array}{l}\text { U.S. consumption of petroleum by-products } \\
\text { (billion GEEGs) }\end{array}$ & 126.37 & -3.76 & -4.29 & -3.99 \\
\hline ROW oil consumption (billion barrels) * & 21.03 & 0.09 & 0.11 & 0.10 \\
\hline ROW gasoline consumption (billion GEEGs) & 451.70 & 2.04 & 2.33 & 2.16 \\
\hline ROW by-product consumption (billion GEEGs) & 489.66 & 2.21 & 2.53 & 2.35 \\
\hline World oil consumption (billion barrels) & 26.45 & -0.07 & -0.08 & -0.07 \\
\hline
\end{tabular}

* ROW - rest of the world

Source: calculated 
Table 4 Market leakage

\begin{tabular}{lccc}
\hline & Tax credit & Mandate & $\begin{array}{r}\text { Mandate \& tax } \\
\text { credit }\end{array}$ \\
\hline Most plausible parameters & 0.812 & 0.787 & 0.801 \\
$\begin{array}{l}\text { Demand for petroleum by-products twice as elastic as } \\
\text { demand for fuel }\end{array}$ & 0.763 & 0.731 & 0.749 \\
ROW oil demand twice as elastic as oil supply & 0.815 & 0.790 & 0.804 \\
ROW oil supply twice as elastic as oil demand & 0.674 & 0.629 & 0.654 \\
$\begin{array}{l}\text { Inelastic fuel demand } \\
\text { Reversal of gasoline and petroleum by-products production } \\
\text { coefficients }\end{array}$ & 0.782 & 0.773 & 0.778 \\
\hline
\end{tabular}

Source: calculated

Table 5 Actual carbon savings of corn ethanol relative to gasoline and corresponding by-products (\%) *

\begin{tabular}{|c|c|c|c|}
\hline & Tax credit & Mandate & $\begin{array}{r}\text { Mandate \& tax } \\
\text { credit }\end{array}$ \\
\hline \multicolumn{4}{|l|}{ Excluding Land Use Change } \\
\hline Most plausible parameters & -2.3 & 0.2 & -1.2 \\
\hline $\begin{array}{l}\text { Demand for petroleum by-products twice as elastic as } \\
\text { demand for fuel }\end{array}$ & 2.6 & 5.8 & 4.0 \\
\hline ROW oil demand twice as elastic as oil supply & -2.6 & -0.1 & -1.5 \\
\hline ROW oil supply twice as elastic as oil demand & 11.5 & 16.0 & 13.5 \\
\hline Inelastic fuel demand & 0.7 & 1.6 & 1.1 \\
\hline $\begin{array}{l}\text { Reversal of gasoline and petroleum by-products production } \\
\text { coefficients }\end{array}$ & 1.2 & 4.2 & 2.5 \\
\hline \multicolumn{4}{|l|}{ Including Land Use Change } \\
\hline Most plausible parameters & -16.0 & -13.5 & -14.9 \\
\hline $\begin{array}{l}\text { Demand for petroleum by-products twice as elastic as } \\
\text { demand for fuel }\end{array}$ & -11.0 & -7.8 & -9.6 \\
\hline ROW oil demand twice as elastic as oil supply & -16.2 & -13.8 & -15.2 \\
\hline ROW oil supply twice as elastic as oil demand & -2.1 & 2.4 & -0.2 \\
\hline Inelastic fuel demand & -12.9 & -12.0 & -12.5 \\
\hline $\begin{array}{l}\text { Reversal of gasoline and petroleum by-products production } \\
\text { coefficients }\end{array}$ & -12.4 & -9.4 & -11.1 \\
\hline
\end{tabular}

* A negative number means that corn ethanol emits more carbon than gasoline.

Source: calculated

\section{REFERENCES}

AL-RIFFAI, P. - DIMARANAN, B. - LABORDE, D. (2010). Global Trade and Environmental Impact Study of the EU Biofuels Mandate. Final report of an external study for the European Commission carried out by CEPII and IFPRI.

CHEN, X. - HUANG, H. - KHANNA, M. (2011). Land Use and Greenhouse Gas Implications of Biofuels: Role of Technology and Policy. Paper presented at the 2011 Agricultural \& Applied Economics Association Annual Meeting, Pittsburgh, Pennsylvania.

CHEN, X. KHANNA, M. (2012). The market-mediated effects of low carbon fuel policies. AgBioForum, 15, (1) 89-105.

CUI, J. - LAPAN, H. E. - MOSCHINI, G. - COOPER, J. (2011). Welfare Impacts of Alternative Biofuel and Energy Policies. American Journal of Agricultural Economics. 93, (5) 1235-1256. http://dx.doi.org/10.1093/ajae/aar053

DE GORTER, H. - JUST, D. R. (2009a). Why Sustainability Standards for Biofuel Production Make
Little Economic Sense. Cato Institute Policy Analysis, No. 647, Washington D.C.

. (2009b). The Economics of a Blend Mandate for Biofuels. American Journal of Agricultural Economics. 91, (3) 738-750. http://dx.doi.org/10.1111/j.14678276.2009.01275.x

DRABIK, D. (2011). The Theory of Biofuel Policy and Food Grain Prices. Working Paper 2011-20. Charles H. Dyson School of Applied Economics and Management, Cornell University. December 2011.

DRABIK, D. - DE GORTER, H. (2010). Biofuels and leakages in the fuel market. Paper presented at the IATRC Public Trade Policy Research and Analysis Symposium 'Climate Change in World Agriculture: Mitigation, Adaptation, Trade and Food Security' Universität Hohenheim, Stuttgart, Germany, June 27-29. DRABIK, D. - DE GORTER, H. - JUST, D. R. (2010). The implications of alternative biofuel policies on carbon leakage. Charles H. Dyson School of Applied Economics and Management Working Paper \# 2010-22, Cornell University, November. 
DU, X. - HAYES, D. (2009). The Impact of Ethanol Production on U.S. and Regional Gasoline Markets. Energy Policy. 37, (8) 3227-3234. doi:

10.1016/j.enpol.2009.04.011

EIDMAN, V. R. (2007). Economic Parameters for Corn Ethanol and Biodiesel Production. Journal of Agricultural and Applied Economics. 39, (2) 345-356.

FARRELL, A. - PLEVIN, R. - TURNER, B. - JONES, A. - O'HARE, M. - KAMMEN, D. M. (2006). Ethanol Can Contribute to Energy and Environmental Goals. Science. 311, (5760) 506-508. http://dx.doi.org/10.1126/science.1121416

GARDNER, B. (2007). Fuel Ethanol Subsidies and Farm Price Support. Journal of Agricultural \& Food Industrial Organization. 5, Article 4 1-20. http://dx.doi.org/10.2202/1542-0485.1188

HAMILTON, J. D. (2009). Understanding Crude Oil Prices. The Energy Journal. 30, (2) 179-206.

HAVRÁNEK, T. - HAVRÁNKOVÁ, Z. - JANDA, K. (2012). Demand for Gasoline is More Price-Inelastic than Commonly Thought. Energy Economics. 34, (1) 201207. http://dx.doi.org/10.1016/j.eneco.2011.09.003 HOCHMAN, G. - RAJAGOPAL, D. - ZILBERMAN, D. (2011). The effect of biofuels on the international oil market. Applied Economic Perspectives and Policy. 33 (3), 402-27. http://dx.doi.org/10.1093/aepp/ppr016

HOFFMAN, L. A. - BAKER, A. (2011). Estimating the Substitution of Distillers' Grains for Corn and Soybean Meal in the U.S. Feed Complex. A Report from the Economic Research Service, USDA.

KOPLOW, D. (2009). State and Federal Subsidies to Biofuels: Magnitude and Options for Redirection. International Journal of Biotechnology. 11, (1, 2) 92126. http://dx.doi.org/10.1504/IJBT.2009.028102

MURRAY, B. C. (2008). Leakage from an Avoided Deforestation Compensation Policy: Concepts, Empirical Evidence, and Corrective Policy Options. NI WP 08-02. Nicholas Institute for Environmental Policy Solutions, Duke University, Durham, NC.
NATIONAL

RENEWABLE

ENERGY

LABORATORY. (2008). Ethanol Basics, Clean Cities Fact Sheet. U.S. Department of Energy, October.

RAJAGOPAL, D. (2013). The Fuel Market Effects of Biofuel Policies and Implications for Regulations Based on Lifecycle Emissions. Environmental Research Letters. 8, (2) 024013. http://dx.doi.org/10.1088/17489326/8/2/024013

RAJAGOPAL, D. - HOCHMAN, G. - ZILBERMAN, D. (2011). Indirect Fuel Use Change (IFUC) and the Life Cycle Environmental Impact of Biofuel Policies. Energy Policy. 39, (1) 228-233. DOI: 10.1016/j.enpol.2010.09.035

RAJAGOPAL, D. - PLEVIN, R. J. (2013). Implications of Market-Mediated Emissions and Uncertainty for Biofuel Policies. Energy Policy 56 (0), 75-82. http://dx.doi.org/10.1016/j.enpol.2012.09.076

SEARCHINGER, T. - HEIMLICH, R. - HOUGHTON, R. - DONG, F. - ELOBEID, A. - FABIOSA, J. TOKGOZ, S. - HAYES, D. - YU, T. (2008). Use of U.S. Croplands for Biofuels Increases Greenhouse Gases through Emissions from Land use Change. Science, 319, (5867): 1238-1240. http://dx.doi.org/10.1126/science.1151861

SUMNER, D. A. (2006). Effects of US Upland Cotton Subsidies on Upland Cotton Prices and Quantities. Annex I to First Written Submission of Brazil to the Panel in United States Subsidies on Upland Cotton (DS 267) Recourse by Brazil to Article 21.5 of the DSU. 17 November.

STOFT, S. (2010). Renewable Fuel and the Global Rebound Effect. Global Energy Policy Center. Research Paper No. 10-06.

WOODERS, P. J. - COSBEY, R. A. (2009). Options for Policy-makers: Addressing Competitiveness, Leakage and Climate Change. Report of the International Institute for Sustainable Development. 
Appendix Data used to calibrate the model

\begin{tabular}{|c|c|c|c|c|}
\hline Variable/parameter & Symbol & Value & Unit & Source \\
\hline $\begin{array}{l}\text { PARAMETERS } \\
\text { Miles per gallon of ethanol relative to } \\
\text { gasoline }\end{array}$ & $\lambda$ & 0.69 & & Cui et al. (2011) \\
\hline Ethanol produced from one bushel of corn & $\beta$ & 2.80 & $\begin{array}{l}\text { gallon/ } \\
\text { bushel }\end{array}$ & Eidman (2007) \\
\hline $\begin{array}{l}\text { DDGS production coefficient } \\
\text { DDGS relative price to corn }\end{array}$ & $\begin{array}{l}\gamma \\
\mathrm{r}\end{array}$ & $\begin{array}{r}17 / 56 \\
0.86\end{array}$ & & $\begin{array}{r}\text { Eidman (2007) } \\
\mathrm{r}=\left(\mathrm{P}_{\mathrm{DDGS}} * 56\right) /\left(\mathrm{P}_{\mathrm{C}} * 2000\right)\end{array}$ \\
\hline Gasoline production coefficient & $\beta_{\mathrm{G}}$ & 21.48 & $\begin{array}{l}\text { gallon/ } \\
\text { barrel }\end{array}$ & $\beta_{\mathrm{G}}=\mathrm{G} / \mathrm{Q}_{\mathrm{O}}^{\mathrm{H}}$ \\
\hline Petroleum by-product production coefficient & $\beta_{\mathrm{B}}$ & 23.29 & $\begin{array}{l}\text { GEEG/ } \\
\text { barrel }^{\text {b }}\end{array}$ & $\beta_{\mathrm{B}}=42 * 1.066-\beta_{\mathrm{G}}$ \\
\hline $\begin{array}{l}\text { Price and quantity link between corn and } \\
\text { ethanol market }\end{array}$ & $\mathrm{k}$ & 2.61 & $\begin{array}{l}\text { GEEG/ } \\
\text { bushel }\end{array}$ & $\mathrm{k}=\lambda \beta /(1-\mathrm{r} \gamma)$ \\
\hline Ratio of additives to gasoline & $\mathrm{K}$ & 0.09 & & $\mathrm{~K}=\mathrm{A} / \mathrm{G}$ \\
\hline Ethanol processing cost & $\mathrm{C}_{0}^{\mathrm{E}}$ & 1.36 & \$/GEEG & $\mathrm{C}_{0}^{\mathrm{E}}=\mathrm{P}_{\mathrm{E}}+\mathrm{s}_{\mathrm{E}} / \lambda-\mathrm{P}_{\mathrm{C}} / \mathrm{k}$ \\
\hline Gasoline processing cost & $c_{0}^{G}$ & 0.83 & \$/GEEG & $\mathrm{C}_{0}^{\mathrm{G}}=\mathrm{P}_{\mathrm{G}}+\beta_{\mathrm{B}} \mathrm{P}_{\mathrm{B}} / \beta_{1}-\mathrm{P}_{\mathrm{O}} / \beta_{\mathrm{G}}$ \\
\hline $\begin{array}{l}\text { Share of domestic consumption of DDGS } \\
\text { POLICY VARIABLES }\end{array}$ & $\omega$ & 0.81 & & Hoffman and Baker (2011) \\
\hline Blend mandate ${ }^{\mathrm{c}}$ & $\alpha$ & 0.06 & & $\alpha=\mathrm{E} / \mathrm{F}$ \\
\hline Ethanol tax credit & $\mathrm{t}_{\mathrm{c}}$ & 0.50 & \$/gallon & $\mathrm{t}_{\mathrm{c}}=\$ 0.45 /$ gal. $+\$ 0.048 /$ gal. $^{\mathrm{d}}$ \\
\hline Ethanol production subsidy & $\mathrm{S}_{\mathrm{E}}$ & 0.14 & \$/gallon & $\begin{array}{l}\text { Assumed to be the same as in } \\
2008^{\text {e }}\end{array}$ \\
\hline Corn production subsidy & $\mathrm{S}_{\mathrm{C}}$ & 0.17 & \$/bushel & $\begin{array}{r}\text { Environmental Working } \\
\text { Group }\end{array}$ \\
\hline Fuel tax & $\mathrm{t}$ & 0.49 & \$/gallon & American Petroleum Institute ${ }^{\mathrm{g}}$ \\
\hline $\begin{array}{l}\text { Tax on petroleum by-products } \\
\text { PRICES }\end{array}$ & $t_{B}$ & 0.16 & \$/gallon & $\mathrm{t}_{\mathrm{B}}=0.33 * \mathrm{t}$ \\
\hline Oil price & $\mathrm{P}_{\mathrm{O}}$ & 61.00 & \$/barrel & Cui et al. (2011) \\
\hline Gasoline price & $\mathrm{P}_{\mathrm{G}}$ & 1.76 & \$/gallon & $\begin{array}{r}\text { Gasoline average rack price in } \\
\text { Omaha, Nebraska }\end{array}$ \\
\hline Ethanol market price (volumetric) & $\mathrm{P}_{\mathrm{e}}$ & 1.79 & \$/gallon & $\begin{array}{r}\text { Ethanol average rack price in } \\
\text { Omaha, Nebraska }{ }^{h}\end{array}$ \\
\hline $\begin{array}{l}\text { Ethanol market price (energy) } \\
\text { Ethanol producer price }\end{array}$ & $\begin{array}{l}\mathrm{P}_{E} \\
\mathrm{P}_{\mathrm{E}}^{\mathrm{P}}\end{array}$ & $\begin{array}{l}2.59 \\
2.79\end{array}$ & $\begin{array}{l}\text { \$/GEEG } \\
\$ / \text { GEEG }\end{array}$ & $\begin{array}{r}\mathrm{P}_{\mathrm{E}}=\mathrm{P}_{\mathrm{e}} / \lambda \\
\mathrm{P}_{\mathrm{E}}^{\mathrm{P}}=\mathrm{P}_{\mathrm{E}}+\mathrm{S}_{\mathrm{E}} / \lambda\end{array}$ \\
\hline Fuel price & $\mathrm{P}_{\mathrm{F}}$ & 2.27 & \$/GEEG & $\begin{array}{r}\mathrm{P}_{\mathrm{F}}=\alpha *\left(\mathrm{P}_{\mathrm{E}}+\mathrm{t} / \lambda-\mathrm{t}_{\mathrm{C}} / \lambda\right)+ \\
(1-\alpha)^{*}\left(\mathrm{P}_{\mathrm{G}}+\mathrm{t}\right)\end{array}$ \\
\hline Market price of petroleum by-products & $\mathrm{P}_{\mathrm{B}}$ & 1.76 & \$/GEEG & Cui et al. (2011) \\
\hline Consumer price of petroleum by-products & $\mathrm{P}_{\mathrm{B}}^{\mathrm{C}}$ & 1.92 & \$/GEEG & $\mathrm{P}_{\mathrm{B}}^{\mathrm{C}}=\mathrm{P}_{\mathrm{B}}+\mathrm{t}_{\mathrm{B}}$ \\
\hline Corn market price & $\mathrm{P}_{\mathrm{C}}$ & 3.75 & \$/bushel & USDA $^{\mathrm{i}}$ \\
\hline Corn producer price & $\mathrm{P}_{\mathrm{C}}^{\mathrm{P}}$ & 3.92 & \$/bushel & $\mathrm{P}_{\mathrm{C}}^{\mathrm{P}}=\mathrm{P}_{\mathrm{C}}+\mathrm{S}_{\mathrm{C}}$ \\
\hline DDGS price & $\mathrm{P}_{\mathrm{DDGS}}$ & 114.38 & $\$ /$ ton & USDA $^{\mathrm{j}}$ \\
\hline
\end{tabular}

Notes:

${ }^{\mathrm{a}}$ DDGS $=$ Dried distillers grains with solubles

${ }^{\mathrm{b}}$ GEEG = Gasoline-energy equivalent gallon

${ }^{\mathrm{c}}$ The blend mandate is expressed in energy terms.

${ }^{\mathrm{d}} \$ 0.45 /$ gallon is the federal component of the tax credit; the $\$ 0.048 /$ gallon is the average state tax credit reported by Koplow (2009).

${ }^{\mathrm{e}}$ Koplow (2009) estimates the U.S. ethanol production subsidies in 2008 to be \$1.356 billion. Ethanol production in 2008 reached

9.6579 billion gallons (EIA).

${ }_{\mathrm{f}}^{\mathrm{h}}$ http://farm.ewg.org/progdetail.php?fips=00000\&progcode=corn (For details on the calculation of the corn subsidy,

see the text of the paper).

${ }^{\mathrm{g}}$ http://www.api.org/statistics/fueltaxes/upload/gasoline-diesel-summary.pdf (average for 2009)

${ }^{\mathrm{h}}$ http://www.neo.ne.gov/statshtml/66.html

${ }^{\mathrm{i}}$ http://www.ers.usda.gov/data-products/feed-grains-database/feed-grains-yearbook-tables.aspx

${ }^{\mathrm{j}}$ http://www.ers.usda.gov/data-products/feed-grains-database/feed-grains-yearbook-tables.aspx\#26818 
Appendix Data used to calibrate the model (continued)

\begin{tabular}{|c|c|c|c|c|}
\hline Variable/parameter & Symbol & Value & Unit & Source \\
\hline $\begin{array}{l}\text { QUANTITIES } \\
\text { World oil production }\end{array}$ & $\mathrm{S}^{\mathrm{W}} \mathrm{O}$ & 26.38 & billion barrels & EIA $^{k}$ \\
\hline Domestic oil supply & $\mathrm{S}_{\mathrm{O}}^{\mathrm{H}}$ & 1.99 & billion barrels & EIA $^{1}$ \\
\hline Oil supply in the Rest of the world & $\mathrm{S}_{\mathrm{O}}^{\mathrm{F}}$ & 24.40 & billion barrels & $\mathrm{S}_{\mathrm{O}}^{\mathrm{F}}=\mathrm{S}_{\mathrm{O}}^{\mathrm{W}}-\mathrm{S}_{\mathrm{O}}^{\mathrm{H}}$ \\
\hline Oil consumption in the Rest of the world & $\mathrm{D}_{\mathrm{O}}^{\mathrm{F}}$ & 21.12 & billion barrels & $\mathrm{D}_{\mathrm{O}}^{\mathrm{F}}=\mathrm{S}_{\mathrm{O}}^{\mathrm{W}}-\mathrm{S}_{\mathrm{O}}^{\mathrm{H}}-\mathrm{S}_{\mathrm{O}}^{\mathrm{M}}$ \\
\hline U.S. oil imports & $\mathrm{S}^{\mathrm{M}} \mathrm{O}$ & 3.27 & billion barrels & EIA $^{1}$ \\
\hline Total oil available in the United States & $\mathrm{Q}_{\mathrm{O}}^{\mathrm{H}}$ & 5.26 & billion barrels & $\mathrm{Q}_{\mathrm{O}}^{\mathrm{H}}=\mathrm{S}_{\mathrm{O}}^{\mathrm{H}}+\mathrm{S}_{\mathrm{O}}^{\mathrm{M}}$ \\
\hline Quantity of petroleum by-products & $\mathrm{Q}_{\mathrm{B}}$ & 122.48 & billion GEEGs & $\mathrm{Q}_{\mathrm{B}}=\beta_{\mathrm{B}} \mathrm{Q}_{\mathrm{O}}^{\mathrm{H}}$ \\
\hline Consumption of petroleum by-products & $\mathrm{C}_{\mathrm{B}}$ & 122.48 & billion GEEGs & $\mathrm{C}_{\mathrm{B}}=\mathrm{Q}_{\mathrm{B}}$ \\
\hline Fuel demand (volumetric) & $\mathrm{f}$ & 134.75 & billion gallons & EIA $^{1}$ \\
\hline Fuel demand (energy) & $\mathrm{F}$ & 131.34 & billion GEEGs & $F=G+A+E$ \\
\hline Ethanol consumption (volumetric) & e & 11.04 & billion gallons & EIA $^{1, m}$ \\
\hline Ethanol consumption (energy) & E & 7.63 & billion GEEGs & $\mathrm{E}=\lambda \mathrm{e}$ \\
\hline Gasoline supply & G & 112.98 & billion gallons & $G=f-A-e$ \\
\hline Imports of fuel additives & A & 10.73 & billion gallons & EIA $^{l}$ \\
\hline Domestic corn supply & $\mathrm{S}_{\mathrm{C}}^{\mathrm{H}}$ & 13.09 & billion bushels & Cui et al. (2011) \\
\hline Domestic yellow corn demand as food/feed & $\mathrm{D}_{\mathrm{C}}^{\mathrm{H}}$ & 7.29 & billion bushels & $\mathrm{D}_{\mathrm{C}}^{\mathrm{H}}=\mathrm{S}_{\mathrm{C}}^{\mathrm{H}}-\mathrm{Q}_{\mathrm{C}}^{\prime}-\mathrm{D}_{\mathrm{C}}^{\mathrm{F}}$ \\
\hline Foreign yellow corn import demand & $\mathrm{D}_{\mathrm{C}}^{\mathrm{F}}$ & 1.86 & billion bushels & Cui et al. (2011) \\
\hline Corn used in ethanol production (initial) ${ }^{n}$ & $\mathrm{Q}_{\mathrm{C}}$ & 2.92 & billion bushels & $\mathrm{Q}_{\mathrm{C}}=\mathrm{E} / \mathrm{k}$ \\
\hline Corn used in ethanol production ${ }^{\circ}$ & $Q_{C}^{\prime}$ & 3.94 & billion bushels & $\mathrm{Q}_{\mathrm{C}}^{\prime}=\mathrm{Q}_{\mathrm{C}} /(1-\mathrm{r} \gamma)$ \\
\hline DDGS supply & DDGS & 1.02 & billion bushels & $\mathrm{DDGS}=\mathrm{r} \gamma \mathrm{Q}_{\mathrm{C}}^{\prime}$ \\
\hline Quantity of domestic DDGS consumption & $\mathrm{DDGS}^{\mathrm{H}}$ & 0.83 & billion bushels & $\mathrm{DDGS}^{\mathrm{H}}=\omega * \mathrm{DDGS}$ \\
\hline Quantity of DDGS exports & $\mathrm{DDGS}^{\mathrm{F}}$ & 0.19 & billion bushels & $\begin{array}{r}\mathrm{DDGS}^{\mathrm{F}}=(1- \\
\omega)^{*} \mathrm{DDGS}\end{array}$ \\
\hline $\begin{array}{l}\text { U.S. domestic consumption of non-ethanol } \\
\text { corn-equivalent }\end{array}$ & $\mathrm{D}^{\mathrm{H}^{\mathrm{H}}}{ }_{\mathrm{C}}$ & 8.12 & billion bushels & $\mathrm{D}^{\mathrm{\prime H}}{ }_{\mathrm{C}}=\mathrm{D}_{\mathrm{C}}^{\mathrm{H}}+\mathrm{DDGS}^{\mathrm{H}}$ \\
\hline $\begin{array}{l}\text { U.S. exports of corn equivalent } \\
\text { ELASTICITIES }\end{array}$ & $\mathrm{D}^{\prime \mathrm{F}}{ }_{\mathrm{C}}$ & 2.06 & billion bushels & $\mathrm{D}^{\prime \mathrm{F}}{ }_{\mathrm{C}}=\mathrm{D}_{\mathrm{C}}^{\mathrm{F}}+\mathrm{DDGS}^{\mathrm{F}}$ \\
\hline Domestic supply elasticity of oil & $\eta_{\text {so }}^{\mathrm{H}}$ & 0.20 & & Cui et al. (2011) \\
\hline Import supply elasticity of oil & $\eta^{\mathrm{M}}$ so & 3.00 & & Cui et al. (2011) \\
\hline Domestic supply elasticity of corn & $\eta_{\mathrm{SC}}^{\mathrm{H}}$ & 0.23 & & Gardner (2007) \\
\hline Domestic demand elasticity of corn & $\eta_{\mathrm{DC}}^{\mathrm{H}}$ & -0.20 & & Cui et al. (2011) \\
\hline Foreign demand elasticity of corn & $\eta_{\mathrm{DC}}^{\mathrm{F}}$ & -1.50 & & Cui et al. (2011) \\
\hline Domestic demand elasticity of fuel & $\eta_{\mathrm{DF}}^{\mathrm{H}}$ & -0.26 & & Hamilton (2009) \\
\hline $\begin{array}{l}\text { Domestic demand elasticity of petroleum by- } \\
\text { products }\end{array}$ & $\eta^{\mathrm{H}}{ }_{\mathrm{DB}}$ & -0.26 & & $\begin{array}{r}\text { Assumed to be the } \\
\text { same as } \eta^{\mathrm{H}}{ }_{\mathrm{DF}}\end{array}$ \\
\hline ROW oil supply elasticity & $\eta_{\text {so }}^{\mathrm{F}}$ & 0.15 & & Assumed \\
\hline $\begin{array}{l}\text { Demand elasticity of oil in the Rest of the } \\
\text { world }\end{array}$ & $\eta^{\mathrm{F}}{ }_{\mathrm{DO}}$ & -0.29 & & $\begin{array}{r}\eta_{\mathrm{DO}}^{\mathrm{F}}=\left(\mathrm{S}^{\mathrm{M}}{ }_{\mathrm{O}} / \mathrm{D}^{\mathrm{F}}{ }_{\mathrm{O}}\right)^{*} \\
\left(\eta_{\mathrm{SO}}^{\mathrm{F}} *\left(\mathrm{~S}^{\mathrm{F}}{ }_{\mathrm{O}} / \mathrm{S}^{\mathrm{M}}{ }_{\mathrm{O}}\right)-\eta^{\mathrm{M}}{ }_{\mathrm{SO}}\right)\end{array}$ \\
\hline $\begin{array}{l}\text { Notes: } \\
\text { k http://www.eia.gov/cfapps/ipdbproject/iedindex3.cfm?t } \\
\text { 2009\&unit=TBPD } \\
{ }^{1} \text { http://www.eia.gov/forecasts/steo/query/ } \\
\mathrm{m}^{\mathrm{m}} \text { Ethanol consumption is assumed to be equal to ethanol } \\
{ }^{\mathrm{n}} \text { This quantity of corn does take into account the market } \\
{ }^{\circ} \text { This quantity of corn takes into account the market effe }\end{array}$ & 5\&pid=57\&a & \&cid=ww, & syid=2009\&eyid= & \\
\hline
\end{tabular}

